\title{
Anti-Breast Cancer Potency of Multistage Extraction from Jamur Dewa (Agaricus blazei Murill) Solvents on MCF-7 Cells
}

\author{
Misgiati $^{1}$, Sukardiman $^{2 *}$, Aty Widyawaruyanti ${ }^{2}$ \\ ${ }^{1}$ AKAFARMA Putra Indonesia, Malang, Indonesia \\ ${ }^{2}$ Universitas Airlangga, Surabaya, Indonesia
}

\begin{abstract}
ABM (Agaricus blazei Murill) is a basidiomycetes fungus. ABM is used by people for the treatment of diabetes, antihypertention, anticholesterol, anticancer, and immunostimulant. $A B M$ contains terpene, steroids, agaritine, vitamin $\mathrm{C}$, vitamin $\mathrm{E}$, and betaglucane. In this research, ABM extract was tested as an anti-breast cancer in vitro using MCF-7 breast cancer cells. The extract was obtained from the multistage extraction process of several solvents in turn, the solvent used, among others, n-hexane, dichloromethane (DCM), chloroform, ethyl acetate, butanol, and water. The results of the research were the obtained $I C_{50}$ value from $n$-hexane extract $247.17 \mu \mathrm{g} / \mathrm{mL}$; extract DCM $227 \mu \mathrm{g} / \mathrm{mL}$; chloroform extract $215.64 \mu \mathrm{g} / \mathrm{mL}$; extract of ethyl acetate $234.9 \mu \mathrm{g} / \mathrm{mL}$; butanol extract $500,78 \mu \mathrm{g} / \mathrm{mL}$; while the water extract was inactive. Based on these results can be considered for further research to fractionate in order to know which class compounds have the potency as anticancer within the extracts.
\end{abstract}

Keywords : Agaricus blazei, multistage extraction, MCF-7 cells.

\section{INTRODUCTION}

Breast cancer is the second most common cancer in women worldwide and in Indonesia. Breast cancer is the most commonly found after cervical cancer. The latest data from the American Cancer Society estimated in 2017 showed that there are approximately 252,710 cases of breast cancer in women, while about 40,610 women died because ofbreast cancer. The number of breast cancer patients in Indonesia is second ranked after cervical cancer. The causes of breast cancer have not be known for certain, but there are several possibilities: (a) genes, i.e., BRCA1, BRCA2, p53, Bcl2 genes are inherited genes that can trigger the breast cancer; (b) the use of certain drugs, such as hormonal therapy; (c) other factors, i.e., not married, married but without children, giving birth to the first child after the age of 35 years, never breastfeeding the child; (d) have had an infection or trauma (Desen, 2008).

Treatments performed for breast cancer patients are chemotherapy, radiotherapy, and surgery. These treatments have negative effects, especially if it is already at metastasis stage. Based on this condition the researchers tried to find alternative treatment using natural ingredients with the aim of minimizing the side effects. One of the natural materials that can be used is Agaricus blazei
Murill (ABM). ABM is a basidiomycetes fungus. People use ABM as a functional food. Empirically $\mathrm{ABM}$ is used as antidiabetic, antihypertention, anticholesterol, anticancer, and immunostimulant. ABM contains $\alpha$ - (1-4) -; $\beta$ - (1-6) -glucan (Fujimiya, et al., 1998), $\alpha$ - (1-6) -; $\alpha$ - (1-4) -glucan, $\beta$ - (1-6) -; $\beta$ - (1-3) -glucan, $\beta$ - (1-6) -; $\alpha-(1-3)$-glucan (Mizuno, et al., 1990), lectins (Kawagishi, et al., 1990), riboglucan (Cho, et al., 1999), glucomannan (Hikichi, et al., 1999), ergosterol Takaku, et al., 2001), sodium pyroglutamate (Kimura, et al., 2004), RNA-protein complex (Gao, et al., 2007), Agaritin (Stijve, et al., 2003; Nagaoka, et al., 2006; Akiyama, et al., 2011), blazein (Itoh and Hibasami, 2008), agariblazepirol C (Hirotani, et al., 2005), ascorbic acid, $\alpha$ - and $\delta$-tocopherol, total phenol (Huang and Mau, 2006).

Based these contents, ABM can be used as an anticancer agent. 50\% ABM ethanol extract can inhibited Hela cell growth with $\mathrm{IC}_{50}$ value 194.4 $\mu \mathrm{g} / \mathrm{mL}$ (Misgiati, 2011). Agaritin isolated from ABM could inhibit the proliferation of U937, MOLT4, HL60 and K562 cells with $\mathrm{IC}_{50}$ values of $2,7,9,4,13$, and $16 \mu \mathrm{g} / \mathrm{mL}$, and in normal lymphatic cells there was no resistance to concentration $40 \mu \mathrm{g} / \mathrm{mL}$ (Akiyama, et al., 2011).

\footnotetext{
*Corresponding author e-mail: maman_ht@yahoo.com
} 
Blazein, which also resulted from ABM isolation, could induce the death of LU99 human lung and stomach KATO III cancer cell line at a concentration of $200 \mu \mathrm{g} / \mathrm{mL}$ (Itoh, et al., 2008). Polysaccharides generated from ABM mightinhibit osteosarcoma cell proliferation (HOS cell line) at the concentration of $100 \mu \mathrm{g} / \mathrm{mL}$. ABM might inhibit proliferation of prostate cancer cells DU145 and PC3 $400 \mu \mathrm{g} / \mathrm{mL}$ and $800 \mu \mathrm{g} / \mathrm{mL}$ (Yu, et al., 2009). Previous research, had not inform the active compound or activity on breast cancer cells MCF-7. The purpose of this study was to find out the active ingredients that have cytotoxic activity against MCF-7 cancer cells.

\section{MATERIALS AND METHODS}

\section{Simplicia Preparation}

All parts of the ABM fungus were used. ABM was cleaned from soil and root, then washed with running water. $\mathrm{ABM}$ dried with oven at $70^{\circ} \mathrm{C}$ temperature until obtained the dried $\mathrm{ABM}$ with water content of not more than $10 \%$.

\section{Extraction}

The amount of 100 grams of dried ABM was added by $\mathrm{n}$-hexane pro analysis (p.a.) for $150 \mathrm{ml}$ and extracted with ultrasonic at $40^{\circ} \mathrm{C}$ for 10 minutes. Extraction was done three times. The resulted filtrate was collected, subsequently evaporated until the solvent allows to be removed for drying. The dregs was extracted using a $150 \mathrm{ml}$ Dichlormetane solvent. The same treatment was carried out in extraction with $\mathrm{n}$-hexane. Other solvents are chloroform, ethyl acetate, n-butanol, and hot water $\left(100^{\circ} \mathrm{C}\right)$.

\section{Ethanol Extract 50\% Preparation}

A hundred grams of dried ABM were immersed in $50 \%$ ethanol as much as $150 \mathrm{~mL}$, allowed to stand for 2 days, then strained. The dregs was again immersed using $50 \%$ ethanol as much as $150 \mathrm{ml}$, strained again. Repeat again for the dregs. Filtrate was collected, evaporated, then dried in $40^{\circ} \mathrm{C}$ oven.

\section{Extracts For Rich Alkaloids Preparation}

Amount of 50\% ethanolic extracts were added by $0.5 \mathrm{~N}$ hydrochloric acid, then added by $2 \%$ ammonium hydroxide.

\section{Identification of Extracts}

The resulting extracts were identified by TLC (Thin Layer Chromatography). The stationary phase used silica gel GF254, while the mobile phase used two eluents. First eluen was hexane: ethylacetate (4: 1) and second eluent was ethyl acetate: methanol: water (0.5: 8: 1.5). Each extract was spotted as much as $5 \mu \mathrm{l}$ on the TLC plate. It was eluted with the available eluent (the eluent used based on observation). Staining for mobile phase n-hexaneethyl acetate was using Lieberman and heating $105^{\circ} \mathrm{C}$, then observed on UV light $254 \mathrm{~nm}$ and 355 $\mathrm{nm}$. Staining for the ethyl acetate-methanol-water mobile phase used Dragendorf.

\section{Cytotoxic Testing}

MCF-7 cells were seeded on microplate 96 wells as much as 5000 cells/wells and incubated for 48 hours to achieve good growth. The MEM medium was replaced with a new one by adding the extract at various concentrations $(0 \mu \mathrm{g} / \mathrm{mL}, 25$ $\mu \mathrm{g} / \mathrm{mL}, 50 \mu \mathrm{g} / \mathrm{mL}, 100 \mu \mathrm{g} / \mathrm{mL}, 200 \mu \mathrm{g} / \mathrm{mL}$, and 400 $\mu \mathrm{g} / \mathrm{mL}$ ) with DMSO as co-solvent and incubating at $37^{\circ} \mathrm{C}$ in a $5 \% \mathrm{CO}_{2}$ incubator for 48 hours. At the end of incubation, MEM media andextracts were discarded and then the cells were washed with PBS. At each well, $10 \mu \mathrm{L}$ of MTT reagent $(5 \mathrm{mg} / \mathrm{mL})$ was added. Cells were incubated for 4-6 hours in a 5\% incubator $\mathrm{CO}_{2}$ of $37^{\circ} \mathrm{C}$. The MTT reaction was discontinued with isopropanol acid reagent $(\mathrm{HCl} 4 \mathrm{~N}$ and isopropanol ; 1:4), shaked gently over the shaker for 10 minutes. Absorption was read by ELISA reader at $550 \mathrm{~nm}$ wavelength. The data collection for the cytotoxic test were: a) The absorbance data obtained from the cytotoxic test that was converted to live cell percent, b) Percent of living cell was calculated using the formula:

$$
\text { Cell viability: } \frac{\text { absorption of cell with treetment - absorption of cell medium control }}{\text { absorption of cell medium - absorption of medium control }} \times 100 \%
$$

\section{RESULT}

The dried ABM had water content of not more than $10 \%$. Extracts resulted from $\mathrm{n}$-hexane solvent with rendement of $0.66 \%, 0.47 \%$ for chloroform solvent, $0.28 \%$ for chloroform solvent, $0.52 \%$ for ethyl acetate solvent, $0.60 \%$ for n-butanol solvent, and $46.97 \%$ for hot water solvent. 
The resulted extracts were identified by TLC. Based on the eluent used n-hexane: methanol (4:1), there were several classes of terpenoid and steroids compounds in the treatment of extraction with $\mathrm{n}$ hexane solvent, dichlormethane, chloroform. (Fig. $1)$, whereas in the eluent of ethyl acetate: methanol: water $(0.5: 8: 1.5)$ there was only a class of alkaloid compound in the treatment of solvent extraction in chloride, chloroform, and n-butanol (Fig. 2).

Result of cell viability as on the diagram below (Fig. 2). Based on the cell viability percentage, resulted $\mathrm{IC}_{50}$ value on each extract as described in table below (Table 1).

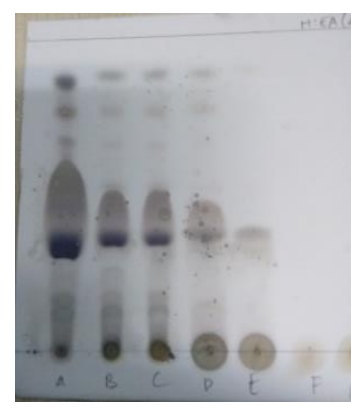

A

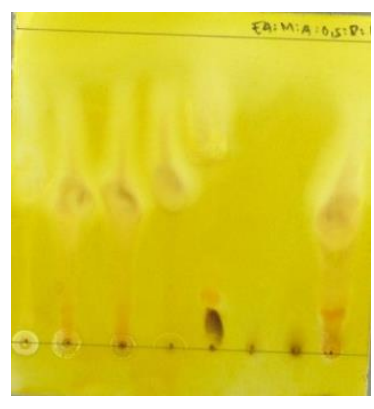

B

Figure I. (A) Terpenoids and steroids compound, (B) Alkaloid compounds.

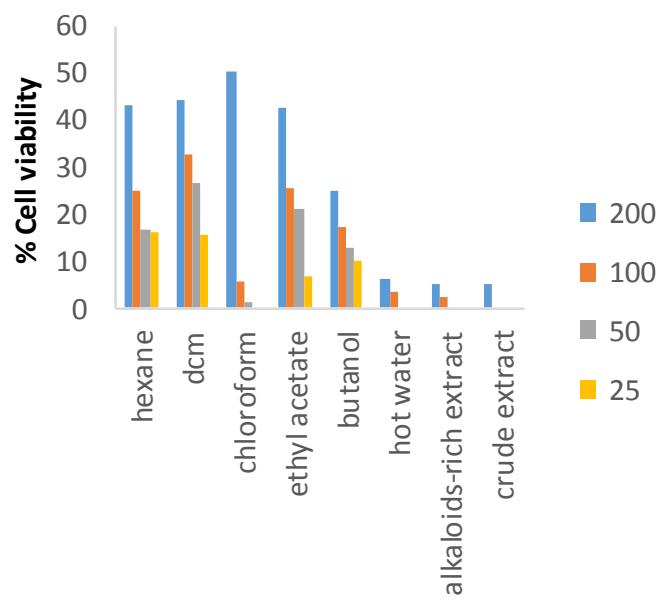

Figure 2. Cell viability of MCF-7 after treatment by extract with some solvents. Cytotoxic test was determined with MTT assay.

\begin{tabular}{ll} 
Table I. IC 50 value from some solvents on ABM $(\boldsymbol{\mu g} / \mathbf{m L})$ \\
\hline \multicolumn{1}{c}{ Kind of extracts } & \multicolumn{1}{c}{$\mathrm{IC}_{50}$ value } \\
\hline n-hexane & 247.17 \\
dcm & 227 \\
chlroform & 215.64 \\
ethyl acetate & 234.90 \\
n-butanol & 500.78 \\
hot water & inactive \\
alkaloids extract & inactive \\
50\% ethanolic extract & 446 \\
\hline
\end{tabular}




\section{DISCUSSION}

Extract with n-hexane solvent had $\mathrm{IC}_{50}$ value of $247 \mu \mathrm{g} / \mathrm{mL}$. Groups of soluble compounds in $\mathrm{n}$ hexane solvent were nonpolar compounds, namely terpenoids and steroids. These were confirmed by the results of identification with TLC showing a positive result. Group of steroids was capable to induce cell death and morphological changes through chromatin condensation causing apoptosis in lung cancer cells LU99 and KATO III stomach cancer cells (Itoh, et al., 2008).

Extract with solvent dichloromethane has had $\mathrm{IC}_{50}$ value of $227 \mu \mathrm{g} / \mathrm{mL}$. Based on the identification with TLC there were terpenoid groups, steroids and alkaloids (Fig. $1 \&$ 2). Likewise for extracts with chloroform solvent that had $\mathrm{IC}_{50}$ of $215.64 \mu \mathrm{g} / \mathrm{mL}$ and ethyl acetate solvent extract, also gave the same color as the solvent extract in the TLC identification. The dichlormethane and the chloroform solvent had a polarity index that was not too far away, so that the group of dissolved compounds in them were not much different from their kind. Extracts with nbutanol and hot water solvents showed no activity, nor did alkaloids-rich extracts and crude extracts.

According to Machana, et al., (2011), the extract having activity as an anticancer has $\mathrm{IC}_{50}$ value of $100-500 \mu \mathrm{g} / \mathrm{mL}$. While chloroform extract of purple tapak leaves (Catharantus ruseus [L] G.Don var roseus) had anticancer activity with $\mathrm{IC}_{50}$ of $188.949 \mu \mathrm{g} / \mathrm{mL}$, and white cypress leaves (Catharantus roseus [L] G.Don var albus) had $\mathrm{IC}_{50}$ of $201.371 \mu \mathrm{g} / \mathrm{mL}$ (Kusumastuti, 2013). Purple and white treads contain classes of alkaloids such as vincristine, vinblastine, catharantin. In the extract of petroleum ether and black cumin chloroform (Nigella sativa), cytotoxicity test was performed on MCF-7, HeLa, and wiDr cells with $\mathrm{IC}_{50}$ values of $164 \mu \mathrm{g} / \mathrm{mL}, 161 \mu \mathrm{g} / \mathrm{mL}, 402 \mu \mathrm{g} / \mathrm{mL}, 267 \mu \mathrm{g} / \mathrm{mL}$, $331 \mu \mathrm{g} / \mathrm{mL}$, and $280 \mu \mathrm{g} / \mathrm{mL}$ (Ekowati, et al., 2011). Other data are Aspergillus sp etil acetate extract and methanol extract: hexane (1:1) having $\mathrm{IC}_{50}$ values of $153.266 \mu \mathrm{g} / \mathrm{mL}$ and $208.305 \mu \mathrm{g} / \mathrm{mL}$ in T47D cells, wherein this extract contains alkaloid secondary metabolites, steroids, terpenoids, polyphenols, flavonoids, phenolic (Winarno, 2011).

\section{CONCLUSION}

Based on the above, ABM extract with nhexane, dichloromethane, chloroform, and ethylacetate solvents have an anticancer ability in MCF-7 cells. This extract can be developed as an anticancer candidate in MCF-7 cells.

\section{ACKNOWLEDGEMENT}

We are grateful to acknowledge to the ASIMAS that have been given samples used for this study.

\section{REFERENCES}

Akiyama, H., Endo, M., Matsui, T., Katsuda, I., Emi, N., Kawamoto, Y., et al., 20II, Agaritine from Agaricus blazei Murrill Induces Apoptosis in the Leukemic Cell Line U937, Biochim. Biophys. Acta., I 8 I 0(5), 519-525.

American cancer society, 2017, Breast cancer: key statistic of breast cancer, http://www.cancer.org/cancer/breastcancer/d etailedguide/breast-cancer-key-statistics, Cited January, IIth 2017.

Cho, S.M., Park, J.S., Kim, K.P., Cha, D.Y., Kim, H.M. and Yoo, I.D., 1999, Chemical Features and Purification of Immunostimulating Ppolysaccharides from the Fruit Bodies of Agaricus blazei, Kor. J. Mycol., 27(2), I70-I74.

Desen, W., 2008, Buku Ajar Onkologi Klnik, 2nd Edition, Jakarta: Fakultas Kedokteran Universitas Indonesia.

Ekowati, H., Prasasti, E. and Rastuti, U., 20II, The Active Fraction from Nigella sativa and its Activity Against T47D Cell Line, Indones. J. Chem., I I (3), 217-222.

Fujimiya, Y., Suzuki, Y., Oshiman, K.I., Kobori, H., Moriguchi, K., Nakashima, H., et al 1998, Selective Tumoricidal Effect of Soluble Proteoglucan Extracted from the Basidiomycete, Agaricus blazei Murill, Mediated Via Natural Killer Cell Activation and Apoptosis, Cancer Immunol. Immunother. 46(3), I47-I59. 
Gao, L., Sun, Y., Chen, C., Xi, Y., Wang, J. and Wang, Z., 2007, Primary Mechanism of Apoptosis Induction in a Leukemia Cell Line by Fraction FA-2-b-ss Prepared from the Mushroom Agaricus blazei Murill, Braz. J. Med. Biol. Res., 40(I I), I545-I 555.

Hikichi, M., Hiroe, E. and Okubo, S., 1999, Protein Polysaccharide 004I. European Patent 0939082, 9 January 1999.

Hirotani, M., Masuda, M., Sukemori, A., Hirotani, S., Sato, N. and Yoshikawa, T, 2005, Agariblazeipirol $\mathrm{C}$ from the Cultured Mycelia of The Fungus, Agaricus blazei, and The Chemical Conversion of Blazeipirol A, Tetrahedron, 6 I (2005), I89- 194.

Huang, S.J. and Mau, J.L., 2006, Antioxidant Properties of Methanolic Extracts from Agaricus blazei with Various Doses of $\mathrm{Y}$ Irradiation, Food Sci. Technol., 39(7), 707-7I6.

Itoh, H., Ito, H. and Hibasami, H., 2008. Blazein of a New Steroid Isolated from Agaricus blazei Murrill (himematsutake) Induces Cell Death and Morphological Change Indicative of Apoptotic Chromatin Condensation in Human Lung Cancer LU99 and Stomach Cancer KATO III Cells, Oncol. Rep., 20(6), |359-|36|.

Kawagishi, H., Kanao, T., Inagaki, R., Mizuno, T., Shimura, K., Ito, H., Hagiwara, T. and Nakamura, T., 1990, Formolysis of a Potent Antitumor $\quad(I \rightarrow \quad 6)-\beta$-d-glucan-protein Complex from Agaricus blazei Fruiting Bodies and Antitumor Activity of the Resulting Products, Carbohydr. Polym., I 2(4), 393-403.

Kimura, Y., Kido, T., Takaku, T., Sumiyoshi, M. and Baba, K., 2004, Isolation of an Anti-Angiogenic Substance from Agaricus blazei Murill: Its Antitumor and Antimetastatic Actions, Cancer Sci., 95(9), 758-764.

Kusumastuti, R., 2013, Efek Ekstrak Kloroform Daun Tapak Dara (Catharanthus roseus [L.] G. Don)
Var. Albus dan Roseus dalam induksi apoptosis berdasarkan ekspresi procaspase-3 pada sel HeLa, Dissertation, Universitas Gadjah Mada, Yogyakarta.

Machana, S., Weerapreeyakul, N., Barusrux, S., Nonpunya, A., Sripanidkulchai, B. and Thitimetharoch, T., 20II, Cytotoxic and Apoptotic Effects of Six Herbal Plants Against the Human Hepatocarcinoma (HepG2) Cell Line, Chin. Med., 6(I), 39, doi: I0.II86/I749-8546-6-39.

Misgiati, M., 20II, Kemampuan Antikanker Ekstrak Jamur Dewa (Agaricus blazei Murill) Pada Sel kanker Serviks Sebagai Bahan Bacaan Pengobatan Tradisional, Thesis, Universitas Negri Malang, Malang.

Mizuno, T., Inagaki, R., Kanao, T., Hagiwara, T., Nakamura, T., Ito, H., et al., 1990, Antitumor Activity and Some Properties of WaterInsoluble Hetero-glycans from "Himematsutake," the Fruiting Body of Agaricus blazei Murill, Agric. Biol. Chem., 54(I I), 2897-2905.

Nagaoka, M.H., Nagaoka, H., Kondo, K., Akiyama, H. Maitani, T., 2006, Measurement of a Genotoxic Hydrazine, Agaritine, and Its Derivatives by HPLC with Fluorescence Derivatization in the Agaricus Mushroom and Its Products, Chem. Pharm. Bull., 54(6), 922-924.

Takaku, T., Kimura, Y. and Okuda, H., 200I, Isolation of an Antitumor Compound from Agaricus blazei Murill and Its Mechanism of Action, J. Nutr., I3 I(5), |409-14I3.

Winarno, E., 20II, Uji Sitotoksik Ekstrak Kapang Aspergillus Sp. terhadap Sel Kanker Payudara T47D, Thesis, Universitas Indonesia, Jakarta.

Yu, C.H., Kan, S.F., Shu, C.H., Lu, T.J., Sun-Hwang, L. and Wang, P.S., 2009, Inhibitory Mechanisms of Agaricus blazei Murill on the Growth of Prostate Cancer In vitro and in vivo, J. Nutr. Biochem., 20(10), 753-764. 